\title{
Population structure of Annona coriacea Mart. (Annonaceae) in different Cerrado phytophysiognomies
}

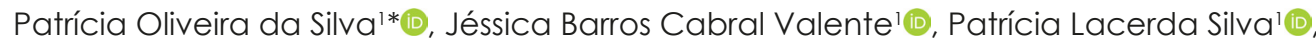 \\ Carolina Ferreira Gomes²(D), Gisele Cristina de Oliveira Menino' (iD) \\ 'Federal Institute Goiano, Rio Verde, Brazil \\ ${ }^{2}$ Faculty of Philosophy Sciences and Letters of Ribeirão Preto, Ribeirão Preto, Brazil \\ *Corresponding author, e-mail: patriciasilvaifgoiano@gmail.com
}

\begin{abstract}
Knowing the regeneration and structure of a species in different phytophysiognomies is extremely important to understand its pattern of occurrence. In spite of its importance, this type of study is still scarce in the Cerrado biome. In this perspective, this work aimed to compare the structure of the arboreal and regenerating strata of Annona coriacea in the cerrado sensu stricto and in the cerradão (savanna woodland). For that purpose, 13 plots of $400 \mathrm{~m}^{2}$ were installed in each physiognomy. All individuals of $A$. coriacea were sampled and had their diameter and height measured. The individuals were divided into regenerating and arboreal and were distributed in classes of height and diameter. Furthermore, the absolute density and the basal area of each extract were calculated in each physiognomy. The parameters were compared using the T-test. In total, 130 individuals of $A$. Coriacea were sampled, with 42 regenerating individuals in the cerrado sensu stricto and 49 in the cerradão. As for the arboreal individuals, 33 were sampled in the cerrado sensu stricto and 6 in the cerradão. All evaluated parameters revealed to be significantly different for the physiognomies. Based on these results, it is possible to affirm that A. coriacea did not present a distribution pattern in the two physiognomies, although it presents a better establishment success in the cerrado sensu stricto. In the cerradão, although the seeds can germinate, the seedlings fail to develop and reach the adult age.
\end{abstract}

Keywords: Araticum, comparison, class distribution, regeneration

\section{Introduction}

The knowledge of the populational density of seedlings and trees is important since it determines the structure and status of regeneration of forest communities (Paul et al., 2019). Therefore, it is necessary to know these factors in order to understand the path that a species is taking in a determined environment, and if this path is towards a decline, it is possible to develop strategies to conserve biodiversity (Dutta \& Devi, 2013). Since this study allows us to understand the history of species disturbances in the past and their environment, it can be used to predict the future trend of populations (Bogale et al., 2017), avoiding threatening situations or even their extinction.

Studies on population structure and regeneration in the Cerrado, although providing important data, are still scarce and therefore necessary. The Cerrado is one of the world hotspots because of its high biodiversity, with a considerable number of endemic species, and constituted by physiognomies that range from open fields to dense forests (Castro et al., 2013). The most threatened physiognomies are the cerradão and the cerrado sensu stricto, which are very required for agricultural purposes (Carvalho et al., 2016) and are floristically similar (PradoJúnior et al., 2012). The difference between these physiognomies is that the cerrado sensu stricto presents a discontinuous shrub-tree stratum with grasses (Silva et al., 2019), whereas the cerradão is a forest formation with a continuous canopy (Borges et al., 2019). Among the families found in these physiognomies, there is the Annonaceae, which in Brazil is represented by 29 genera and nearly 378 species, of which 147 are endemic (Flora do Brasil, 2020).

Annona is the main genus of the family Annonaceae, with fruit species and interesting properties (Oliveira Junior et al., 2014). Among its species, Annona 
coriacea Mart. (or Araticum) is widely distributed throughout the Cerrado physiognomies (Flora do Brasil, 2020) and presents medicinal properties (Gomes et al., 2019). Seed dormancy occurs by embryo immaturity, which consists of the meristematic tissues of the embryo not being totally differentiated when dispersion occurs. The seeds of this species are usually dispersed under conditions of high temperature (summer) in the Cerrado, being afterward exposed to a low-temperature period (autumn/winter) that allows them to overcome physiological dormancy through this thermal transition (hot/cold). As a matter of fact, root protrusion and seedling emergence occur only in the spring, when temperatures are favorable (Dresch et al., 2014).

In spite of the importance of this species, studies regarding its regeneration and establishment in Cerrado physiognomies are nonexistent. In view of this, this study aimed to compare the regeneration of $A$. coriacea in the cerrado sensu stricto and in the cerradão to answer the following questions: Are the populations of $A$. coriacea regenerating in the two studied phytophysiognomies? Does A. coriacea present a population structure pattern in the two physiognomies?

\section{Material and Methods}

Characterization of the study area

The present study was developed in a Cerrado remnant located at the Fontes do Saber Farm (17\%47' 12 " $S$ and $50^{\circ} 57^{\prime} 48^{\prime \prime} \mathrm{W}$ ), belonging to the University of Rio Verde, state of Goiás, Brazil. According to Alvares et al. (2013), the region presents an Aw-type climate (typical tropical), alternately wet (October to April) and dry (May to September). Climates of this category present temperatures above $18{ }^{\circ} \mathrm{C}$ in the coldest month and rainfall under 2.000 millimeters per year. The study area occupies approximately 40.5 hectares, and is constituted by the two main Cerrado physiognomies, namely cerrado sensu stricto and cerradão.

The soil of the study area is classified as a Dystrophic Red Latosol (Santos et al., 2018). Soil samples were collected at the depth from 0.0 to $0.20 \mathrm{~m}$ in different spots and then homogenized for the chemical and particle size characterization of both physiognomies. The results are presented in Table 1.

Table 1. Chemical and particle size characterization of the Dystrophic Red Latosol (Oxisol) in the cerrado sensu stricto and cerradão at the Fontes do Saber Farm, municipality of Rio Verde, Goiás.

\begin{tabular}{|c|c|c|c|c|c|c|c|c|c|c|c|}
\hline Physiognomy & $\mathrm{pH}$ & $\mathrm{Ca}^{2+}$ & $\mathrm{Mg}^{2+}$ & $\mathrm{P}$ & $K$ & CEC & O.M & $\mathrm{V}$ & Clay & Silt & Sand \\
\hline & & \multicolumn{4}{|c|}{$\mathrm{mg} / \mathrm{dm}^{3}$} & $\mathrm{cmol} / \mathrm{dm}^{3}$ & $\mathrm{~g} / \mathrm{Kg}^{1}$ & \multicolumn{4}{|c|}{$\%$} \\
\hline Sen. stricto & 4.2 & 0.4 & 0.2 & 12 & 82 & 5.5 & 27 & 15 & 48 & 29 & 23 \\
\hline Cerradão & 4.4 & 1.8 & 0.6 & 8 & 112 & 9.1 & 35 & 30 & 29 & 18 & 53 \\
\hline
\end{tabular}

Sampling and data collection

For data collection, 13 permanent systematic plots with $20 \times 20 \mathrm{~m}$ dimensions and distanced from each other by $10 \mathrm{~m}$ were installed in each physiognomy (Figure 1), totaling 26 plots of $400 \mathrm{~m}^{2}\left(10.400 \mathrm{~m}^{2}\right)$. All individuals of A. coriacea within the plots were identified, numbered, and measured for their height and diameter. The in loco identification occurred with the aid of the specialized literature, and the plant material was collected and incorporated to the herbarium of the Federal Institute of Goiás (Instituto Federal Goiano), Campus Rio Verde, under the registration number 907.

The diameter of the regenerating individuals was measured close to the soil with a digital pachymeter, whereas the adults (circumference at $30 \mathrm{~cm}$ from the ground (CAS) $\geq 10 \mathrm{~cm}$ ) had their circumference measured with a measuring tape. The height was measured with the aid of a graduated rod. The regenerating individuals were distributed into four height classes (class $1=<0.3 \mathrm{~m}$; class $2=\geq 0.3<0.6 \mathrm{~m}$; class $3=\geq 0.6<1.2 \mathrm{~m}$, and class $4=\geq 1.2$ $\mathrm{m}$ ), as well as the arboreal ones (class $1=<1.3$; class $2=$ $\geq 1.3<2.6$; class $3=\geq 2.6<5.2$, and class $4=\geq 5.2 \mathrm{~m}$ ).
The regenerating individuals were also distributed into four diameter classes (class $1=<1 \mathrm{~cm}$; class $2=\geq 1<2 \mathrm{~cm}$; class $3=\geq 2<4 \mathrm{~cm}$, and class $4=\geq 4 \mathrm{~cm}$ ), as well as the arboreal ones (class $1=>3<6 \mathrm{~cm}$; class $2=\geq 6<12 \mathrm{~cm}$; class $3=\geq 12<24 \mathrm{~cm}$, and class $4=\geq 24 \mathrm{~cm}$ ). The calculations and distributions were performed using the software Excel for Windows, and the results were expressed in graphics, also elaborated in the Excel software.

Besides class distribution, the number of individuals, absolute density, and basal area of each extract (regenerating and adults) were also calculated in each physiognomy and estimated for one hectare. The parameters were compared by the T-test using the Sisvar statistical software (Ferreira, 2014).

\section{Results}

The population of $A$. coriacea in both physiognomies summed 130 individuals (125 ind. ha ${ }^{-1}$ ),

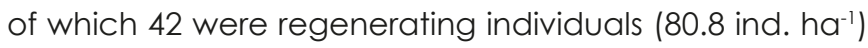
in the cerrado sensu stricto and 49 (94.2 ind. ha-1) in the

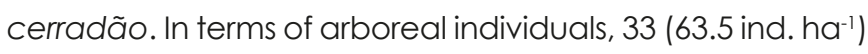
were found in the cerrado sensu stricto and only 6 (11.5 
ind. $\mathrm{ha}^{-1}$ ) in the cerradão. Statistically, the density verified between the physiognomies and between the strata was significantly different $(p<0.05)$.

The total basal area of the regenerating individuals in the cerrado sensu stricto physiognomy was $0.0072 \mathrm{~m}^{2}$, whereas the arboreal ones registered $0.3809 \mathrm{~m}^{2}$. For the cerradão, the basal area of the regenerating individuals was $0.006 \mathrm{~m}^{2}$, and the arboreal, $0.058 \mathrm{~m}^{2}$. The basal area verified between the physiognomies and between the strata was also significantly different $(p<0.05)$.
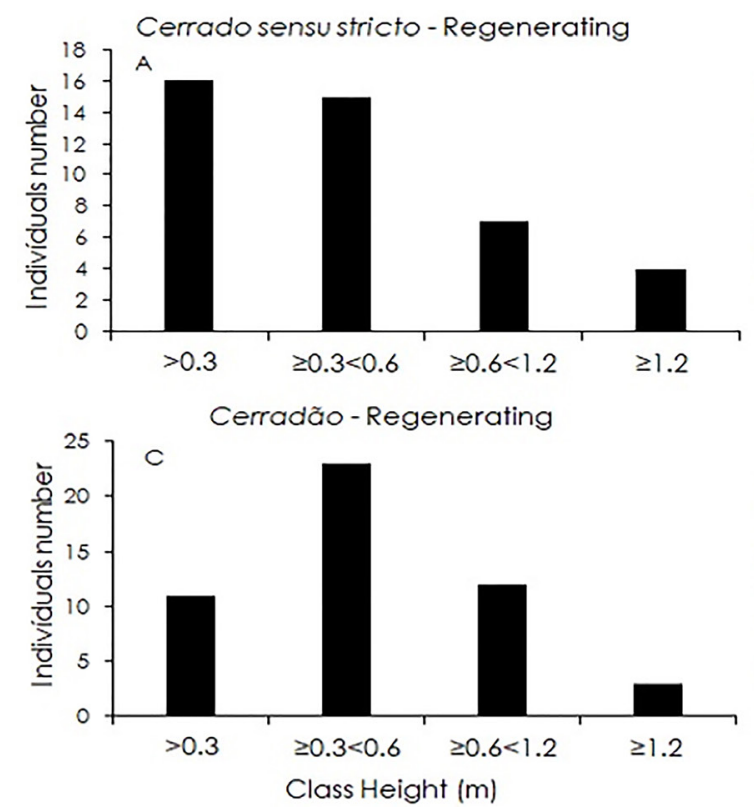

Figure 1. Height distribution of regenerating and arboreal individuals of Annona coriacea Mart. (Annonaceae) in the cerrado sensu stricto (A and B) and cerradão (C and D) in the municipality of Rio Verde, Goiás.

Regarding the distribution of the diametric classes, the regenerating individuals in both physiognomies presented a similar pattern, in which the highest concentration was in class 1 (24 individuals for the cerrado sensu stricto and 34 for the cerradão), decreasing the number of individuals as the classes increased (Figure $2 \mathrm{~A}$ and $\mathrm{C}$, respectively). In the cerrado sensu stricto, the number of regenerating individuals decreased as the number of arboreal individuals increased (Figure 2B).

For the cerradão, the distribution of arboreal individuals did not present a pattern, with a very low number of trees of the species when compared with the result of the cerrado sensu stricto and with the regenerating individuals in the same physiognomy, with 3 individuals in the first class, 1 in the second, and 1 in the third class (Figure 2D).

\section{Discussion}

The results of this study indicate that the regeneration of $A$. coriacea in the cerrado sensu stricto is occurring more efficiently than in the cerradão. In
In the cerrado sensu stricto, the height class distribution of the regenerating individuals, represented in Figure 1A, points to a higher concentration of individuals in the first two classes ( 16 and 15 ind., respectively), reducing as height increases, as seen in class 3 (7 ind.) and class 4 (4 ind.). The arboreal individuals concentrated in higher numbers in class 3 (21 ind.) (Figure 1B). For the cerradão, both regenerating and arboreal individuals were more concentrated in the second class, 23 and 3, respectively (Figure $1 C$ and D).

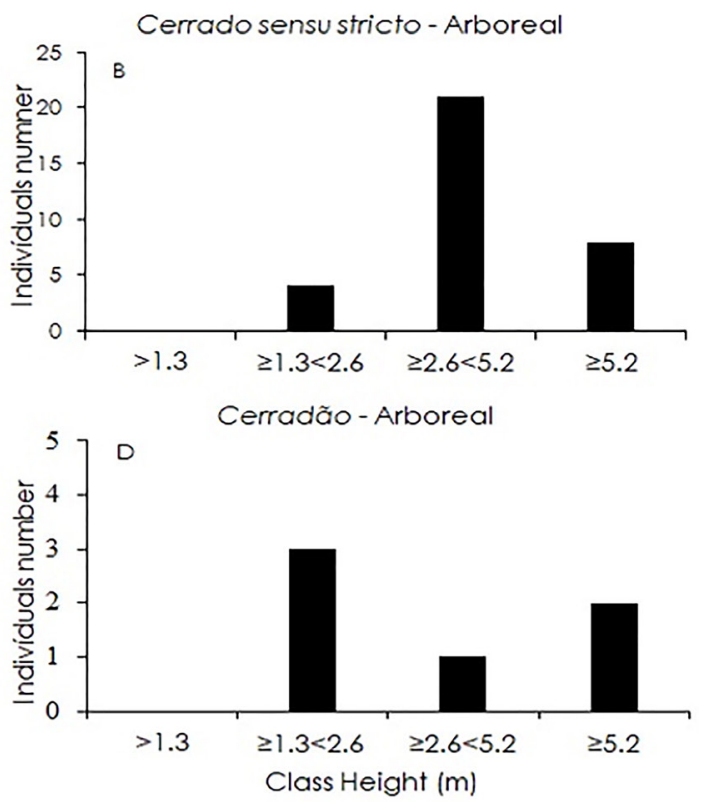

contrast, the cerradão, even presenting a higher number of regenerating individuals than the cerrado sensu stricto, does not present a pattern since very few individuals are reaching the adult age. A. coriacea may not be establishing itself efficiently in the cerradão physiognomy due to its biological characteristics, as a pioneer (Costa et al., 2017) and heliophile (Durigan et al., 2011). Pioneer species develop in clearings, forest edges, and open places, being clearly dependent on higher luminosity conditions (Paula et al., 2004), as depicted in Figure 3. Heliophile species, in their turn, are plants whose seeds require clearings to germinate, and their seedlings dot not survive in shade (Maciel et al., 2003). In this manner, the local distribution of species in a forest community is strongly influenced by the differences in light availability, which conditions either directly or indirectly a large part of plant growth processes (Walter, 1971). Furthermore, plants that grow under favorable conditions, with high levels of nutrients and luminosity, have a greater capacity to defend against or tolerate soil pathogens (McCarthyNeumann \& Kobe, 2018). Due to these characteristics, it 

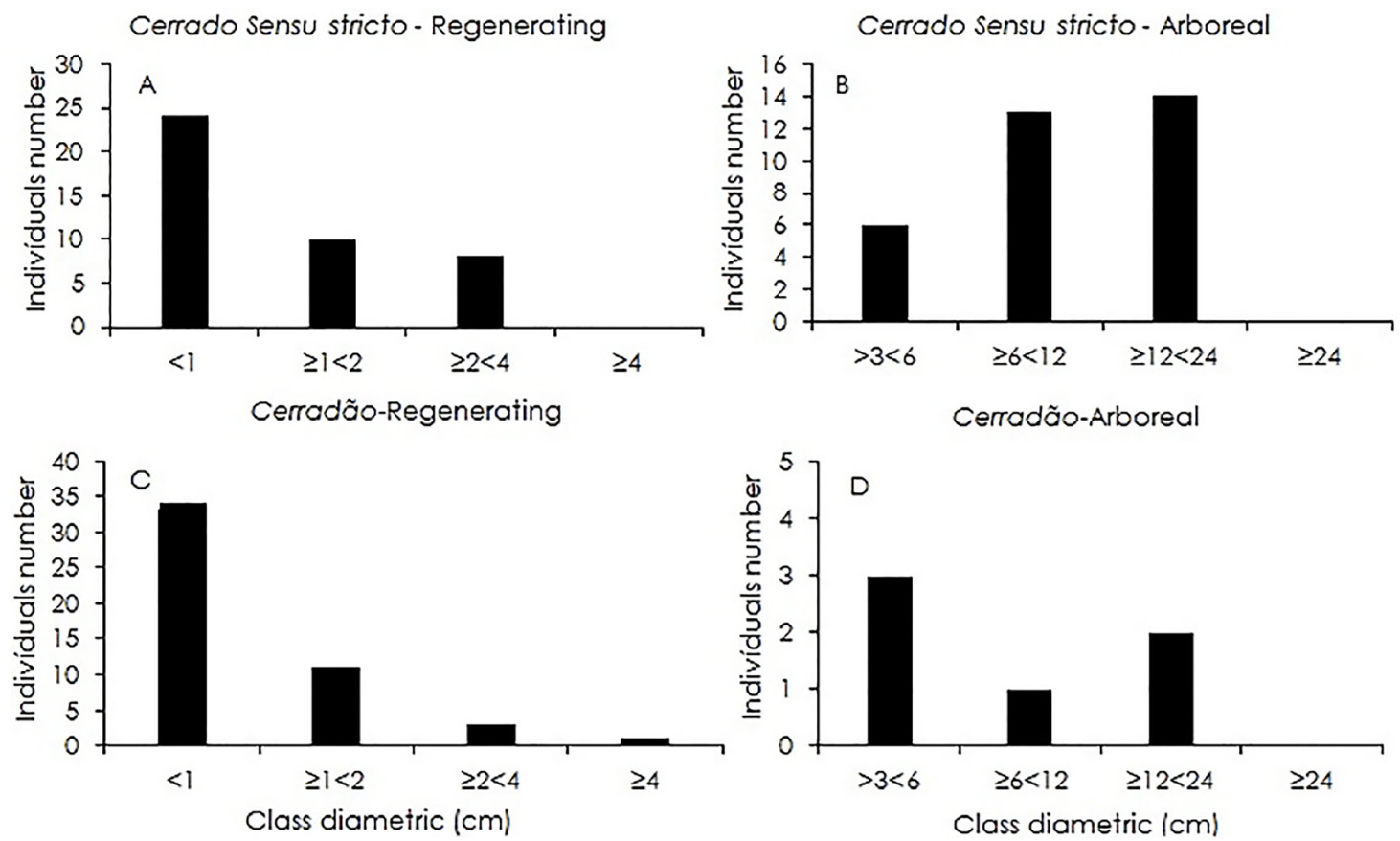

Figure 2. Diametric distribution of regenerating and arboreal individuals of Annona coriacea Mart. (Annonaceae) in the cerrado sensu stricto ( $A$ and B) and cerradão ( $C$ and $D$ ) in the municipality of Rio Verde, Goiás.
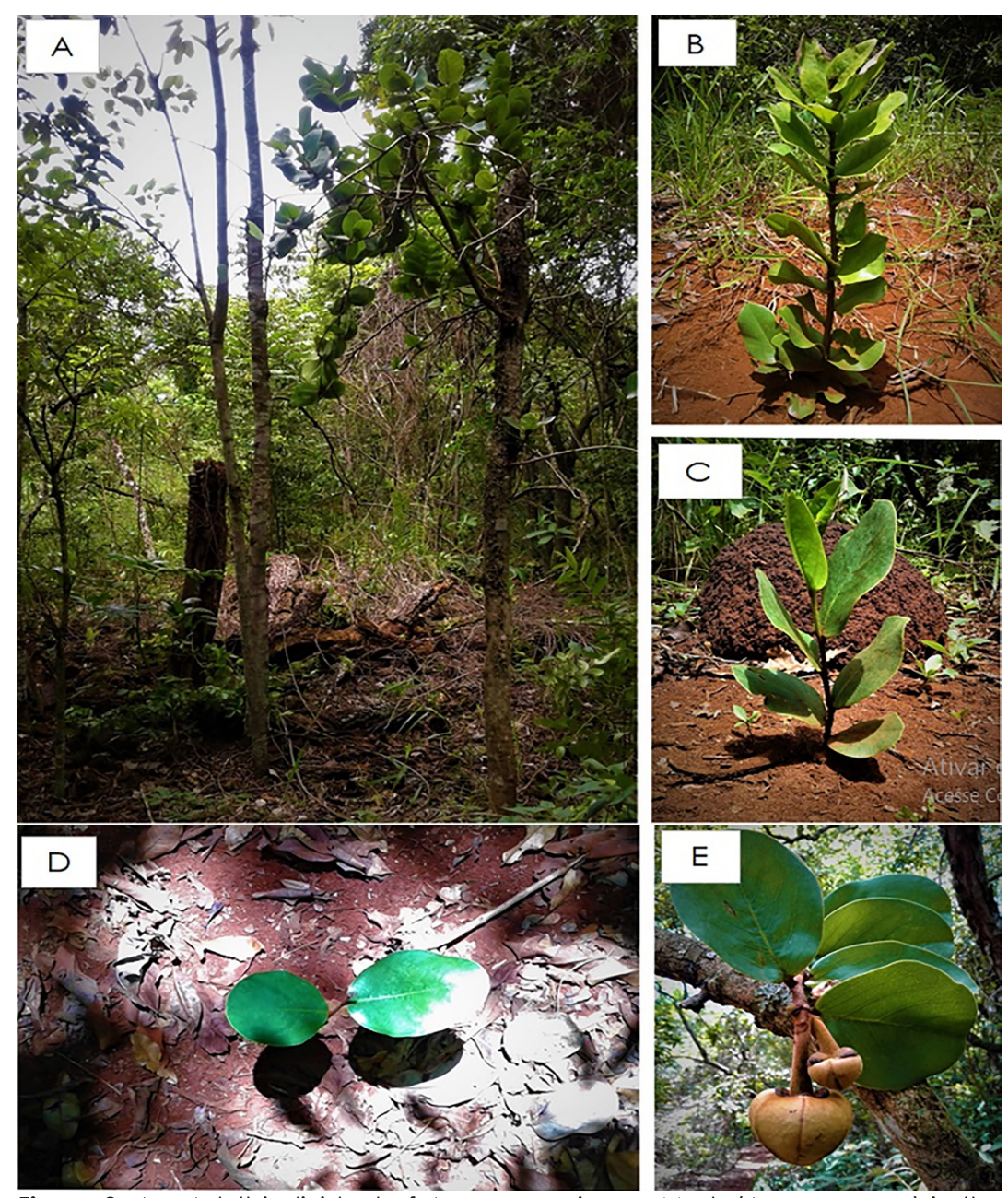

Figure 3. A - Adult individual of Annona coriacea Mart. (Annonaceae) in the study area resuming growth after the fall of a tree beside created a clearing. B and C - Young individuals receiving light incidence in the cerrado sensu stricto. $D$ - Light incidence on an individual growing in the cerradão physiognomy through a clearing. E - Flower buds of A. coriacea (Source: The authors, 2020). 
is believed that although the cerradão presents the best nutritional conditions (Table 1), the seedlings are failing to obtain sufficient luminosity to survive and reach tree size.

The canopy covering is an important ecological factor that influences plant growth (Meira-Neto et al., 2018). However, the cerradão is a denser and taller forest formation, with trees that can reach up to $18 \mathrm{~m}$, forming a practically closed canopy (Andrade et al., 2002). In regions covered with dense vegetation, only a small fraction of solar radiation reaches the soil, being variable in space and time (Januário et al., 1992). Apparently, this may be damaging the establishment of $A$. coriacea in the cerradão since, in nutritional terms, this physiognomy presents better conditions than the cerrado sensu stricto (Table 1) and even so, seedling establishment is not occurring efficiently. Nevertheless, the number of regenerating individuals in the cerradão is higher than in the cerrado sensu stricto.

Given this information, new questions arise: How does the cerradão, although with less luminosity, present a higher number of regenerating individuals? If the species is light-demanding, how can these seedlings in the cerradão reach the stage verified in this study? The higher content of sand present in the cerradão soil may be increasing seed germination. Cavalcante et al. (2008) corroborate this information, registering higher germination of seeds of another species of the genus Annona in substrates containing medium-textured sand. Sand is an inert material of low water retention, due to its high porosity, resulting in higher oxygenation for root development, which are adequate characteristics for the germination of Araticum seeds (Cavalcante et al., 2008). Considering this information, associated with the fact that the canopy opening of dense vegetations favors the growth and establishment of light-demanding species (Van Kuijk et al., 2014), and also considering that seed dormancy overcoming in A. crassiflora occurs by low temperatures or fluctuations (thermal oscillations) that precede the rainy season (Silva et al., 2007), we hypothesized that $A$. coriacea uses the dry period in the study area to increase seed germination while seedlings boost their growth. At this time, the trees not only partially lose their leaves, allowing greater light entry, but lower temperatures also occur. However, in spite of the predictable tree canopy growth with the advance of the rainy season, culminating in canopy closure and limiting luminosity, which even results in growth reduction, the seeds still germinate. In theory, this would allow finding a high number of regenerating individuals, but not of arboreal individuals since only those close to clearings or forest edges would be able to reach an adult size without compromising growth. However, new studies are necessary to confirm this hypothesis.

The cerradão, even presenting a higher number of regenerating individuals, contained an inferior basal area $\left(0.006 \mathrm{~m}^{2}\right)$ to that found in the cerrado sensu stricto $\left(0.0072 \mathrm{~m}^{2}\right)$. Zervoudakis et al. (2012) affirmed that the biomass of roots, stems, leaves, and entire plants decreases under low light intensity, especially in lightdemanding species such as the one of the present study, causing both growth and biomass accumulation to be delayed and occur very slowly. This can be attributed to the low availability of light to the photosystem and, consequently, to the reduced transpiration and stomatal conductance (Mielke \& Schaffer 2010). Trees that receive more light grow significantly faster than those under shade (in the case of light-demanding plants), that is, a clear trend towards decrease is observed for the mean increment in stem thickness with the decrease in the amount of light received by the canopy (Maciel et al., 2002). This explains the lower number of arboreal individuals in the largest classes, both in diameter and in height, compared with that found in the cerrado sensu stricto.

Regarding the height of regenerating individuals, it is noted that the majority of the individuals in both cerradão and cerrado sensu stricto physiognomies are in class 1 and 2, still presenting a mortality risk since, according to Felfili et al. (2000), only individuals with height equal to or above one meter represent the regenerative potential of the arboreal community, having already overcome the strong selective action of the environment and thus passed the critical mortality period. Natural events such as fire, flood, wind, drought, extreme temperatures, and light conditions can affect seedling survival (Singh et al., 2020). These factors, in the cerradão, must have been occurring in the opposite way to what is necessary for the establishment and growth of A. coriacea.

\section{Conclusions}

Annona coriacea did not present a distribution pattern in the two physiognomies, although in the cerrado sensu stricto it is regenerating with higher establishment success. In the cerradão, although the seeds succeed in germinating, the seedlings fail to develop and reach the adult age.

\section{Acknowledgments}

We are grateful to the Laboratory of Plant Systematics and Ecology - Herbarium belonging to the Federal Institute Goiano, Campus Rio Verde (IF GoianoCampus Rio Verde), and to the institution itself. 


\section{References}

Alvares, C.A., Stape, J.L., Sentelhas, P.C., De Moraes Gonçalves, J.L., Sparovek, G. 2013. Köppen's climate classification map for Brazil. Meteorologische Zeitschrift 22: 711-728.

Andrade, L.A.Z., Felfili, J.M., Violatti, L. 2002. Fitossociologia de uma área de cerrado denso na Recor-IBGE, BrasíliaDF. Acta Botânica Brasílica 16: 225-240.

Bogale, T., Datiko, D., Belachew, S. 2017. Structure and natural regeneration status of woody plants of Berbere afromontane moist forest, Bale zone, South East Ethiopia: Implication to biodiversity conservation. Open Journal of Forestry 7: 352-371.

Borges, M.G., Rodrigues, H.L.A., Leite, M.E. 2019. Sensoriamento remoto aplicado ao mapeamento do Cerrado no Norte de Minas Gerais e suas fitofisionomias. Caderno de Geografia 29: 819-835.

Carvalho, M.A.F., Bittar, P.A., Souza, P.B., Ferreira, R.Q.S. 2016. Florística, fitossociologia e estrutura diamétrica de um remanescente florestal no município de Gurupi, Tocantins. Revista Verde de Agroecologia e Desenvolvimento Sustentável 11:59-66.

Castro, M.N., Castro, R.M., Souza, P.C. 2013. A importância da mata ciliar no contexto da conservação do solo. Revista Eletrônica de educação da Faculdade Araguaia 4: 230-241.

Cavalcante, T.R.M., Naves, R.V., Seraphin, J.C., Carvalho, G.D. 2008. Diferentes ambientes e substratos na formação de mudas de araticum. Revista Brasileira de Fruticultura 30: $235-240$.

Costa, M.S., Silva, R.J., Paulino-Neto, H.F., Pereira, M.J.B. 2017. Beetle pollination and flowering rhythm of Annona coriacea Mart. (Annonaceae) in Brazilian cerrado: Behavioral features of its principal pollinators. Plos one 12: $1-14$.

Dresch, D.M., Scalon, S.P.Q., Masetto, T.E. 2014. Effect of storage in overcoming seed dormancy of Annona coriacea Mart. seeds. Anais da Academia Brasileira de Ciências 86: 2077-2085.

Durigan, G., Melo, A.C.G., Max, J.C.M., Vilas Boas, O., Contieri, W.A., Ramos, V.S. 2011. Manual para recuperação da vegetação de cerrado. CETESB, São Paulo, Brazil. 19 p.

Dutta, G., Devi. A. 2013. Plant Diversity, Population Structure, and Regeneration Status in Disturbed Tropical Forests in Assam, Northeast India. Journal of forestry Research 24: 715-720.

Felfili, J.M., Ribeiro, J.F., Fagg, C.W., Machado, J.W.B. 2000. Recuperação de matas de galeria. Embrapa Cerrado, Planaltina, Brazil. 45 p.

Ferreira, D.F. 2014. Sisvar: A Guide for Its Bootstrap Procedures in Multiple Comparisons. Ciência e Agrotecnologia 38: 109-112.

Flora do Brasil 2020. 2020. Jardim Botânico do Rio de
Janeiro. http:floradobrasil.jbrj.gov.br. <Access on 17 Nov. 2019>

Gomes, I. N.F., Silva-Oliveira, R.J., Silva, V.C.B., Rosa, M., Vital, P.S., Barbosa, M.C.S., Santos, F., Junqueira, J.G.M., Severino, V.G.P., Oliveira, B.G., Romão, W., Reis, R.M., Ribeiro, R.I.M.A. 2019. Annona coriacea Mart. Fractions Promote Cell Cycle Arrest and Inhibit Autophagic Flux in Human Cervical Cancer Cell Lines. Molecules 24: 1-16.

Januário, M., Viswaana Dham, Y., Senna, R. C. 1992. Radiação solar dentro e fora de floresta tropical úmida de terra firme (Tucuruí-Para). Acta Amazônica 22: 335340.

Maciel, M.N.M., Watzlawick, L.F., Schoeninger, E.R., Yamaji, F.M. 2002. Efeito da radiação solar na dinâmica de uma floresta. Revista Ciências Exatas e Naturais 4: 101112.

Maciel, M.N.M., Watzlawick, L.F., Schoeninger, E.R., Yamaji, F.M. 2003. Classificação ecológica das espécies arbóreas. Revista Acadêmica: ciências agrárias e ambientais 1: 69-78.

McCarhty-Neumann, S., Kobe, R.K. 2018. Site Soil-Fertility and Light Availability Influence Plant-Soil Feedback. Frontiers in Ecology and Evolution 7: 1-10.

Meira-Neto, J.A.A., Silva, M.C.N.A. da, Tolentino, G.S., Gastaver, M., Buttschardt, T., Ulm, F., Máguas, C. 2018 Shading, nitrogen and soil texture rule a sandy savanna: Does facilitation rule its patchy physiognomy as well? Flora 239: 45-51.

Mielke, M.S., Schaffer, B. 2010. Photosynthetic and growth responses of Eugenia uniflora L. seedlings to soil flooding and light intensity. Environmental Experimental of Botany 68: 113-121.

Oliveira Junior, R.G., Rabêlo, S.V., Araújo, C.S., Silva, J.C., Diniz, T.C., Almeida, J.R.G.S. 2014. Prospecção Tecnológica do gênero Annona (Annonaceae). Revista GEINTEC 4: 850-858.

Paul, A., Khan, M.F., Das, A.K. 2019. Population structure and regeneration status of rhododendrons in temperate mixed broad-leaved forests of western Arunachal Pradesh, India. Geology, Ecology and Landscapes 3: 168186.

Paula, A., Silva, A.F., Marco Júnior, P., Santos, F.A.M., Souza, A.L. 2004. Sucessão ecológica da vegetação arbórea em uma Floresta Estacional Semidecidual, Viçosa, MG, Brasil. Acta botânica brasílica 18: 407-423.

Prado-Júnior, J.A., Lopes, S.F., Do Vale, V.S., Dias Neto, O.C., Schiavini, I. 2012. Comparação florística, estrutural e ecológica da vegetação arbórea das fitofisionomias de um remanescente urbano de cerrado. Bioscience Journal 28: 456-471.

Santos, H.G., Jacomine, P.K.T., Anjos, L.H.C., Oliveira, V.A., Lumbreras, J.F., Coelho, M.R., Almeida, J.A., Araújo Filho, J.C., Oliveira, J.B., Cunha, T.J.F. 2018. Sistema brasileiro de classificação de solos. 5.ed. Embrapa, Brasília, Brazil. $356 \mathrm{p}$. 
Silva, E.A., Melo, D.L. de, Davide, A.C., Bode, N., Abreu, G.B., Faria, J.M.R., Hilhorst, H.W.M. 2007. Germination ecophysiology of Annona crassiflora seeds. Annal of Botany 99: 823-830.

Silva, G.E., Guilherme, F.A.G., Carneiro, S.E.S., Pinheiro, M.H.O., Ferreira, W.C. 2019. Heterogeneidade ambiental e estrutura da vegetação arbustivo-arbórea em três áreas de Cerrado sentido restrito no Sudoeste goiano. Ciência Florestal 29: 924-940.

Singh, S., Sharma, k., Sharma, D. 2020. Natural regeneration status of Terminalia chebula Retz. in Hamirpur district of Himachal Pradesh. Journal of Pharmacognosy and Phytochemistry 9: 284-287.

Van Kuijk, M., Anten, N.P., Oomen, R.J., Schieving, F. 2014. Stimulating seedling growth in early stages of secondary forest succession: a modeling approach to guide tree liberation. Frontiers in Plant Science 5: 1-13.

Walter, H. 1971. Ecology of tropical and subtropical vegetation. T. \& A. ConstableLTD, Edinburg, UK. 29 p.

Zervoudakis, G., Salahas, G., Kaspiri, G., Konstantopoulou, E. 2012. Influence of Light Intensity on Growth and Physiological Characteristics of Common Sage (Salvia officinalis L.). Brazilian Archives of Biology and Technology 55: 89-95.

Conflict of Interest Statement: The authors declare that the research was conducted in the absence of any commercial or financial relationships that could be construed as a potential conflict of interest.

All the contents of this journal, except where otherwise noted, is licensed under a Creative Commons Attribution License attribuition-type BY. 